\title{
From Classroom Management to Policymaking: Identification of Strategies to Improve Education in Sub-Saharan Africa
}

\author{
${ }^{1}$ Jerome St-Amand, ${ }^{2}$ Sofyan Alhamid \\ ${ }^{1}$ Université du Québec en Outaouais, ${ }^{2}$ University of Alberta
}

\begin{abstract}
This study aimed at identifying practical strategies to improve education in sub-Saharan Africa. Using written questionnaires, the data of this study were collected from three new Canadians who were born in sub-Saharan Africa and who now work in the Canadian educational system at primary and university level. The educational challenges we examined concern girls' enrollment in schools, the development of schools in rural areas, the ineffectiveness of teaching and, finally, parents' influence on their children's schooling. The juxtaposition of the participants' experiences in the African educational system and in the Canadian educational system provided practical strategies that we divided into four categories: educational, social, legal, and financial. The notion of "progress" is discussed in light of our results.
\end{abstract}

\section{Introduction}

Sub-Saharan Africa is the part of the African continent south of the Sahara. It is also known as Black Africa, as its populations are predominantly black in color, as opposed to North Africa (called White Africa), which is predominantly white-skinned or tanned (e.g., Egyptians, North Africans). The territory of sub-Saharan Africa is divided into four subregions. These are West Africa (commonly known as West Africa), East Africa, Central Africa, and Southern Africa. In all, there are 48 countries in sub-Saharan Africa according to the World Bank. When one is interested in sub-Saharan Africa, it is difficult to ignore the demographic explosion that characterizes this part of the planet [15], [21]. According to Henri Leridon, director of research at the National Institute of Demographic Studies, the population of Africa will double by 2100 , and this demographic transition will be out of proportion with that of other nations on the planet. In fact, in only one century, from 1950 to 2050, the African population will be multiplied by nearly eleven.

This growing demographic invariably brings pressure on governments, including the need to provide accessible education for all children. However, the current educational context of sub Saharan Africa is so difficult that millions of children today do not even receive basic education despite the 1948 Universal Declaration of Human Rights, which states that access to education is a fundamental right. Considering this problem, the World Bank works toward the development of programs and strategies aimed at improving several sectors of activity, such as education, basic health services, the safety of water and its treatment, agriculture, business climate, infrastructure, and institutional reforms. It is in this context that the World Bank has recently announced massive investments (57 billion US dollars over the next three years) to address the many challenges facing sub- Saharan Africa [2].

Although the quality of education has improved around the world in recent decades, more than 617 million children still cannot reach a minimum level of reading and math skills. Overall, six out of ten children and adolescents do not learn the minimum skills in reading and math. Of the 617 million children and adolescents in this situation, there are 387 million elementary school children and 230 million high school adolescents. In sub-Saharan Africa, 202 million children and adolescents leave the education system without mastering the minimum skills [25]. In that same region of the planet, estimates show that more than 30 million children do not even receive a basic education [24]. Several problems are interrelated to explain the lack of schooling of millions of young Africans. Not intended to be an exhaustive list, we can mention: (1) the lack of access to schools making it impossible for young people to develop academic skills; (2) the inability to keep all children in school and to keep them persevering; (3) the poor quality of educational provision and teaching (e.g., qualified teachers, basic equipment, teaching materials, etc.); (4) household vulnerability [6], [11], [25]. This list raises the need not only to understand the obstacles to children's schooling, but also the urgency of identifying strategies to improve education in these countries.

In light of the above, this article aims at identifying practical strategies that can respond to 
already identified problems (as we will see in detail in the next section) related to the education of thousands of young Africans who fail to begin or pursue their schooling. In more specific terms, the objective of this research is to identify practical strategies in order to:

1) Support girls' education;

2) Improve both the educational availability in rural areas and the quality of teaching;

3) Support students' parents;

4) Assist sub-Saharan governments in addressing the challenges of education in their countries.

\section{Literature review}

A large number of studies and reports have identified factors that increase school dropout rate and the inability of young people in sub-Saharan Africa to attend school. Indeed, challenges are numerous and refer, for example, to violent conflicts [13], to educational policies [16], or to individuals' poor health [27], to name a few. Given the complexity of these challenges, solutions are not necessarily straightforward to develop, and practical strategies are sometimes difficult to find. In this perspective, the present conceptual framework of this study is based on recent work by Inoue, di Gropello, Taylor, and Gresham [11] that sought to illustrate the prevailing situation in the education of young people in subSaharan Africa. More precisely, these authors present:

an overview of the situation of out-of- school children in sub-Saharan Africa that examines the factors that determine young people's decisions either to stay or leave school [...]. This overview examines the main factors underlying out-of-school children and [...] it focuses on the cohort of 12-24-year olds, which are those who are most likely to drop out of high school. (p. 21) (loose translation)

According to this study, six factors constitute the essence of the problems of schooling among young people living in sub-Saharan Africa who are unable to begin or pursue their schooling. We grouped these factors into three categories: (1) girls' enrollment in schools; (2) rural schools and quality of education; (3) parental influence. These three categories corroborate the work of other authors who have examined school dropout in Latin America (more precisely in Brazil). These researchers suggest an interdependence between family, children, and school characteristics [11]. Although we must not lose sight of the particular context of sub-Saharan Africa, it is interesting to note that the phenomenon of dropping out of school shares common explanatory axes with Brazil.

\subsection{Category 1: Girls' enrollment in schools}

Before examining the precarious situation of girls in terms of schooling, let us briefly review some data to have a picture of the situation of young Africans (aged 12-24 years) living in sub-Saharan Africa. Currently, more than half of them are out of school and one in five children have never been enrolled in school. These alarming data add to the fact that more than $43 \%$ of out- of-school children in the world live in sub-Saharan Africa [11]. In more precise terms, many young people do not enroll in school or leave school before they reach high school. Despite this, access to education in these countries has improved significantly. Indeed, school enrollment rate at the elementary level has increased by one-third and the gap between girls and boys has narrowed. In addition, there is an increase in children moving from elementary to high school [23]. Nevertheless, the needs of children in sub-Saharan Africa remain considerable and the situation of girls is still worrying.

The above-mentioned improvements should not overshadow the marital status of thousands of young girls living in sub-Saharan Africa. In fact, child marriage is a major element that favors dropout because many girls are just unable to attend an educational institution. To date, almost $40 \%$ of girls in sub-Saharan Africa are married before the age of 18 , and $12 \%$ are married before the age of 15 [8]. In fact, girls who marry at a young age have fewer years of schooling [12], show more health problems (especially when they give birth at frequent time intervals), and report more unwanted pregnancies than girls who marry as adults [19]. In a context of cohabitation, the domestic work of married girls takes precedence over getting a proper education [11]. If major changes are not made to this problem, the number of married girls in Africa will double by 2050 . As a result, it will become the region of the world with the largest number of child marriages [26].

The current situation in which thousands of young people drop out or never attend school is unacceptable in the twenty-first century. This is particularly the case for thousands of girls who, faced with the responsibility of maintaining a marital relationship at a very young age, see their probability of receiving proper education diminish very early in life. Therefore, the low level of girls' education remains a complex challenge in this part of the world.

\subsection{Category 2: Rural schools and quality of teaching}

In addition to the problematic situation of young girls, which certainly deserves our full attention, the fact of living in rural areas and the inability of schools to provide quality education in sub-Saharan Africa are major obstacles to school perseverance (and even for school attendance) [11], [14]. In fact, young people 
living in cities are more devoted to schooling than rural children. More specifically, seven out of ten young people living in rural areas have never been to school [11]: "Thus, a young urban in the age group $12-14$ years old is $8 \%$ more likely to be in school than a rural youth of the same age group." This undeniably represents a major challenge for society and government authorities wishing to develop their territory. In addition, living in rural areas in subSaharan Africa is a major constraint, particularly because of the complex logistics involved in constructing buildings and maintaining schools, as well as the difficulty of retaining teachers in these areas [1].

In addition to the difficulties accessing school, especially for young people living in rural areas, the quality of the educational provision remains deficient. Indeed, the characteristics related to this ineffective education refer to factors such as insecurity, low salaries, demotivation, as well as the quality of initial and continuing training that do not meet the needs of the teaching community [14]. The above factors are combined with other elements such as the lack of clear and rigorous objectives from the school administrators [11]. In addition, the lack of support from teachers is also a factor that plays a role in students' dropping out: "Students who drop out of school consider that teachers are not interested in them and hold school discipline for inefficient and unfair" [14]. Despite the lack of good quality educational provision, it is important not to lose sight of the important challenges teachers face in subSaharan Africa on a daily basis, and that educational effectiveness depends on several external factors. As Lauwerier and Akkari point out [14]:

[...] we find that the teaching profession in Africa is caught between two important imperatives. The first concerns macroeconomic balances and the need for countries in the region to have their budgets under control. The second concerns the desire to ensure minimum conditions for teachers to work. However, these two imperatives are contradictory, since the former favors contracting, which negatively influences the attractiveness of the profession and teachers' motivation. (loose translation)

In sum, access to school is difficult for a very large number of children living in rural areas of subSaharan Africa. In fact, the logistics are complex both for the retention of teachers and for the construction of new schools. At the same time, the quality of education is lacking and teacher training is problematic, which contributes to students' school dropout and non- attendance.

\subsection{Category 3: Parental influence}

Parental influence is considered as an element that may affect the engagement of young people in school [7], particularly because of the support that parents can offer to their child [7], [5]. As Alexander, Entwisle and Horsey [3] point out: "The family guides children's development in their schooling." In an African context, researchers indicate that parents' level of education has a positive influence on the level of education of their children [4]. According to Inoue, di Gropello, Taylor, and Gresham [11], there is a "transmission in the sense that schooling and quality of life are correlated from one generation to the next." Data make it possible to fully appreciate this observation. In African families where one parent has completed high school, children would be $20 \%$ more likely to persevere throughout their schooling compared to African families with parents who have not completed high school [11].

In addition to the impact of parental education, the household's earning capacity is another factor influencing the education of African children. More specifically, the household's earning capacity - that is the number of adults working in the family - is a factor that influences whether or not young people choose to go to school [11]. For these researchers, children living in a family where adults work are more likely to attend school, while being more likely to finish primary school and continue to high school level. In fact, the probability of going to school increases by $21 \%$ for young people with working parents and increases by $14 \%$ to $15 \%$ the chances of the child going to school without having to be employed at the same time [11]. The need to work can possibly be explained by the high costs of education and the State's disempowerment in this regard. As noted by Hillman and Jenkner [10]:

Because basic education is a recognized right and the education of children is beneficial to society as a whole, it is the State that must be in charge of it, including the cost of educating children. Yet in many poor countries the State do not fulfill this obligation. (loose translation)

All things considered, parents' level of education and earning capacity, as measured by the number of adults working in the household, are significant barriers to children's schooling. These factors are in addition to other obstacles related to the children's schooling, such as the proximity of schools, the quality of education, or the girls' enrollment in schools. This literature review is in line with the standard input-process-output approach that was presented in the 2002 Global Monitoring Report [22], which stresses the importance of examining specific 
components when looking at school improvements in sub-Saharan Africa:

- Classroom factors (e.g., instructional strategies, etc.)

- School factors (e.g., leadership, etc.)

- System factors (e.g., vision, resources, etc.)

- Community factors (home environment, support for education, etc.)

\section{Scientific relevance of this study}

The current study is very important for several reasons. First, sub-Saharan Africa faces many challenges related to educational provision that inevitably have negative consequences for the development of African countries. In fact, many economists and social scientists have quantified the costs of inadequate education. These researchers have identified multiple repercussions affecting several sectors of activity in a context where the academic requirements remain high for individuals. These studies identified broad categories of social repercussions that are associated with dropping out of school, such as tax and financial losses [20], declining health quality [18], as well as increased crime rates and higher costs related to the justice system[17]. Hankivsky [9] corroborates these observations by emphasizing that: "Directly or indirectly, high school non-completion has enormous fiscal implications in terms of expenditures on health, social services and programs, education, employment, criminality, and lower economic productivity."

Providing quality education enables nations to develop fully. It is therefore essential to overcome the obstacles to school dropout in sub-Saharan Africa, which is a fundamental and complex task. Thus, we believe it is essential to give an opportunity to participants to share their experiences because they know the educational context in sub-Saharan Africa. Moreover, it is relevant to better understand the points of view of those participants who know both school systems. The juxtaposition of the participants' academic experiences in both African and Canadian contexts seems important to us because of the gap

\section{Results}

\subsection{Sociodemographic information}

Conducted in the summer of 2017, the data were collected from three professionals (Table 1) who studied in sub-Saharan Africa as well as in North between the two school systems. On the one hand, there is the effectiveness of the Canadian school system and, on the other, the innumerable challenges facing sub-Saharan Africa in this sphere of activity.

\section{Methodology}

We used a qualitative survey method to collect the data for this research. We have specifically opted for a written questionnaire for two reasons: first, it was not easy to find participants of African origin with a rich academic experience in both Africa and North America (Canada). When we found the participants (who lived in different parts of Canada (e.g., Montreal, northern Alberta)), it was easier for us to send them the questionnaire via email than to meet each one of them face-to-face. Besides, the type of questions required allowing the participants time to think carefully. Thus, the use of a written questionnaire greatly favored the participants' opportunities to deepen their thoughts. We therefore thought that it was more appropriate to proceed by means of a written questionnaire.

\subsection{Questionnaire development}

To overcome the challenges associated with this type of survey, a few factors were considered in the elaboration of the questionnaire. Following the clarification of the research objectives, as well as the conceptual and theoretical framework, we developed a comprehensive questionnaire encompassing all facets of this study. To enable all participants to fully understand the questions, we wrote them in a simple, clear, and precise way so that we avoided the use of ambiguous terms or specialized terminology. To help participants understand the context of the study, we made sure that the questionnaire began with a section explaining the parameters of the study, such as the objectives of the research. In addition, the questionnaire was divided into two sections: the first section aimed at obtaining the participants' sociodemographic background, and, the second, the participants' answers regarding the three categories of challenges.

America. The participants now teach in Canada, either at primary or university level. Participants (two men and one woman) are all from Africa (Cameroon, Côte d'Ivoire) and are aged between 45 and 52 years. Two of the participants have $\mathrm{PhDs}$ while the third participant has a Bachelor of Education from a Canadian institution. 
Table 1. Information on participants

\begin{tabular}{cccccccccc} 
Pseudonym & Gender & Age & $\begin{array}{c}\text { Country } \\
\text { of origin }\end{array}$ & $\begin{array}{c}\text { Mother } \\
\text { tongue }\end{array}$ & $\begin{array}{c}\text { Highest } \\
\text { level of } \\
\text { schooling }\end{array}$ & $\begin{array}{c}\text { Elementary } \\
\text { education }\end{array}$ & $\begin{array}{c}\text { High } \\
\text { school } \\
\text { education }\end{array}$ & $\begin{array}{c}\text { University } \\
\text { education }\end{array}$ & $\begin{array}{c}\text { Professional } \\
\text { experience } \\
\text { in North } \\
\text { America }\end{array}$ \\
\hline Balin & M & 49 & $\begin{array}{c}\text { Ivory } \\
\text { Coast }\end{array}$ & $\begin{array}{c}\text { Krou- } \\
\text { Bété }\end{array}$ & $\begin{array}{c}\text { PhD } \\
\text { (Canada) }\end{array}$ & $\begin{array}{c}\text { Ivory Coast, } \\
\text { public } \\
\text { education }\end{array}$ & $\begin{array}{c}\text { Ivory } \\
\text { Coast, } \\
\text { public } \\
\text { education }\end{array}$ & $\begin{array}{c}\text { Ivory } \\
\text { Coast and } \\
\text { Canada }\end{array}$ & $\begin{array}{c}\text { Lecturer and } \\
\text { Assistant } \\
\text { Professor } \\
(2006-\end{array}$ \\
present)
\end{tabular}

\subsection{Results analysis}

In the analysis, we focused on drawing from the data the main themes related to the objectives of this research. We were specifically interested in identifying practical strategies and recommendations that the participants proposed in their answers, and which of course aim at improving education in subSaharan Africa. To analyze the collected data, we will use the content analysis method.

The participants suggested, in order to improve education in sub-Saharan Africa, strategies in response to the objectives of this study (support the education of young girls; improve both the educational availability in rural areas and the quality of instruction in its schools; support students' parents; assist sub-Saharan governments in addressing the challenges of education in their countries). For our part, we divided the participants' strategies into four categories: educational, social, legal, and financial, which encompass the elements of our conceptual framework (classroom factors, school factors, system factors, community factors). Regarding the participants' recommendations, they will be presented in a table following the analysis of the collected data.

\subsection{Educational level}

With regard to specific educational strategies related to support for girls' education, the participants (Sitamze and Balin) focused on improving existing school structures. For Balin, it is crucial to have single-gender schools where women will play a greater role, particularly in terms of the education offered to young girls. In this context, specific values should be conveyed, such as independence and autonomy. For his part, Sitamze indicates that "schools should be less formal (not structured like
Western schools), but rather structured to correspond to the values of the local populations." Educational innovation is therefore at the heart of what this participant said; indeed, the latter proposes the development of a "mobile" educational structure, that is schools and teachers that can accompany nomadic tribes, as is the case in several African countries. Thus, this participant gives as an example the nomadic pastoralists from Niger, Cameroon, Mali, Libya, and Algeria. In this context, the creation of new schools in the regions which are greatly affected by the low enrollment rate of young girls would be essential and beneficial. To this end, individual, community, and social parameters should be considered while taking advantage of public and private actors: "A partnership could be set up between the State (public) and the private sectors (promoters) as well as other international bodies." Schools, on the other hand, should create better conditions (less stressful and more flexible) that would offer students more freedom in a less "constraining" environment. As far as teaching practices are concerned, Sitamze suggests that they should be more effective in order to create a better learning climate that takes into account local cultures. Also, the choice of pedagogical practices should be based on convincing and conclusive data aiming at fulfilling students' basic needs. These comments echo those of Sam who indicates that the effectiveness of pedagogy should be comparable to that found in North America, while taking into account the local cultures, values, and beliefs.

To improve both the educational provision in rural areas and the quality of teaching, the various African governments have a great role to play in terms of infrastructure, training, and schools' supervision. Sitamze suggests that we should build new infrastructures and pay attention to their geographical location. In other words, the geographical scattering of schools does not favor the maximization of 
educational provision in sub-Saharan Africa. As this participant suggests: "Schools should be located at the points of conjunction of several communities." These new schools, of course, should be of superior quality, and built with sustainable materials while providing students with the necessary materials for quality learning (e.g., books, computers, Internet, etc.). Besides these new school infrastructures located in more suitable places to serve as many young people as possible, this participant believes that it would also be necessary to improve schools' supervision located in rural areas: "It would be necessary to have a better follow-up by the State (e.g., ministries of education) of rural schools that are generally not taken care of. There needs to be constant monitoring, evaluation, and coaching [...]." In addition, the professional training of teachers should be improved: "We must also provide training and professional development; most rural teachers are not sufficiently well trained and are not up-to-date with the latest education trends."

\subsection{Social level}

With regard to the social level, Balin and Sitamze think that raising awareness among African communities is key to encourage girls' education. As Balin points out, urbanization has caused (and still causes) the exodus of young people to the cities and, by extension, encourages girls' education: "The main thing would be [therefore] to carry out public awareness campaigns in cities [to promote the importance of students' education]." Balin said the campaign should aim at increasing the safety of young girls: "One of the main strategies is to prevent sexual abuse of girls in African schools." Sitamze adds that this awareness campaign should be conducted with parents to promote the importance of girls' education and its contribution to the economy. For the latter, in addition to parents, the awareness campaign should be conducted with community elites, groups of women and men, hunters, farmers, or by regional area (e.g., from pygmies' camp to camp). This participant says that this awareness campaign should be extended to several African countries in which girls are generally destined for marriage, procreation, and housework; Sitamze cites, as an example, the Kirdi tribe in northern Cameroon, the pygmies found in Gabon, Cameroon, Equatorial Guinea, and the Central African Republic.

To improve both the education provision in rural areas and the quality of instruction in schools, Balin says that parents need to encourage children's education in such a way that they do not require them to work long hours instead of going to school: "It is also necessary to educate parents to let children who are old enough to go to school, and avoid taking them to work in fields or farms while other children continue their schooling." To put it differently,
Sitamze adds that "it is well known that rural people use child labor while minimizing the importance of education which has no direct and rapid impact on their income." Sitamze suggests that it is imperative to find solutions based on collaborative discussions between school entrepreneurs, parents, communities, and governments: "Work must be done to raise awareness and the involvement of people and rural communities."

In order to support parents to take a more active role in the education of their children, Balin and Sitamze believe that it is essential to carry out awareness campaigns with parents to raise the importance of school with them. In this context, Sitamze explains that "in Africa, many parents only set foot in schools for the registration of their children (the first registration), and [after that] never again return. Many are not interested in school life or even in their child's behavior at school." This participant mentions that parents "first and foremost need to understand the why and how of school." In the same vein, Sam, says that "parents need to be more involved in school and extracurricular activities by informing them of their children's academic achievement [...]."

\subsection{Financial level}

At the financial level and with the aim of strengthening the education of young girls, political action should be taken by government authorities. Specifically, Balin raises the importance of effective government lobbying to increase girls' education. For Balin, governments' financial contributions are indispensable and should increase in the coming years through, for example, scholarships that encourage the pursuit of higher levels of education. For his part, Sitamze believes that governments should ensure that developers (public or private) pay for the costs of children's education, while effectively overcoming resistance to change. With regard to educational provision in rural areas, Balin raises the importance of supervising those responsible for financial expenses in these areas. He insists that "we must not let villages themselves make the expenditures of creating schools." Sitamze adds that the improvement of education in rural areas will greatly depend on the standard of living of the inhabitants. This participant said that it is important for parents living in rural areas that their economic situation is comfortable enough so that they can invest a large part of their income in their children's education. Sam, for her part, indicates the importance of giving financial support to parents.

\subsection{Legal level}

To support girls' education, Balin emphasizes the safety of young girls by highlighting the role that governments could play, particularly in improving laws and rules on sexual harassment; laws still 
penalize a large number of young girls. Another legal element derives from another of Balin's answers, this time with regard to parents' support for the schooling of their children. Balin believes it is important to pass laws that will encourage governments to invest in parents' support. More specifically, Balin considers it important to favor the economy as being of service to the parents: "it is necessary to reduce, if not eliminate, the impoverishment of peasants, villagers, and students' parents. This also goes through the participation of the government in school investments; helping parents is of paramount importance as well as the valorization of agricultural products through their purchase at fair prices."

Table 2. Recommendations

\section{Participants}

Recommendations

\begin{tabular}{|c|c|}
\hline Sitamze & $\begin{array}{l}\text { - Design better education policies } \\
\text { - apevote a significant portion of public budgets to education, and pay special attention to rural schools by in providing them } \\
\text { - Improve pupilteacher ratio } \\
\text { - Raise awareness among communities and parents about the importance of education } \\
\text { - Improve supervision of staff working in schools } \\
\text { - Create special needs schools } \\
\text { - Provide financial support to organizations working in education }\end{array}$ \\
\hline Balin & $\begin{array}{l}\text { - Invest in edacation and make it a national priority } \\
\text { - Massive recruitment of primary, high school, and university teachers } \\
\text { - No wearing of school uniforms because many parents cannot afford them } \\
\text { - Regular inspections of schools to have minimum infrastructure standards }\end{array}$ \\
\hline Sam & - Invest in educational research and training to improve the quality of the pedagogy \\
\hline
\end{tabular}

policies without knowing whether, beforehand, the work teams display the capacity to complete the educational

\section{Discussion}

In this study, we reviewed some of the challenges that hinder youth education in sub-Saharan Africa. More specifically, this study aimed at identifying strategies to support young girls' education, support students' parents, improve both the educational availability in rural areas and the quality of teaching. All this is an effort to assist sub-Saharan governments in addressing the challenges of education in subSaharan Africa. This research has

raised strategies that we have grouped into four categories: educational, social, financial, and legal.

Beyond these strategies, the fundamental element that embraces these strategies refers to the notion of "progress" that reflects the need to evolve collectively and positively in terms of the necessary transformation that local communities in Africa desperately need. However, at first glance, a surface analysis of the many educational challenges in Africa could lead to the wrong conclusion that this "progress" is mainly dependent on the level of funding provided (e.g., building new schools, purchasing school materials, conducting effective awareness campaigns, etc.). Without downplaying the importance of funding, we believe that this thesis remains rather simplistic, if not incomplete, and that the funding granted is only one component in the equation of this desired transformation.

In our opinion, this "progress" could be largely dependent on three interdependent axes of action: (1) the quality of the policies put in place; (2) the level of competence of the actors concerned; and (3) the capacity of the teams to get the work done. In this context, we argue that this educational transformation will be partly the result of the quality of the policies put in place for and by the people, that is to say policies aimed at supporting the interests of everyone. Despite their great importance, effective policies and financial resources are just two ingredients of the "progress" envisioned. Skilled human capital should not be overlooked (e.g., public servants, teachers, principals, etc.) in this equation; this should lead intellectuals in targeted African countries as well as G7 leaders (France, Canada, Germany, Italy, Japan, United States, United Kingdom) to better define their respective contribution and commitment to training future leaders in sub-Saharan Africa.

Ultimately, the capacity to get the work done cannot be overlooked considering the complex strategies envisioned in this study. It is obvious and inconceivable to give large sums of money and vote 
for effective project or the mandate of the Ministries of Education. The effective implementation would be facilitated, in our view, by many factors such as adequate funding, effective education policies, and the active involvement of many highly qualified professionals as well as by intellectuals committed to social change. It is therefore essential to identify the levers of success and to target the obstacles ahead, in particular by consulting experts and consulting firms. We reaffirm the importance of encouraging local communities to participate in the process of change and invite the international community to invest massively in the future of our greatest collective wealth: our children.

\section{References}

[1] Agence française de développement, Agence universitaire de la Francophonie, Orange \& UNESCO (2012). Le numérique au service de l'éducation en Afrique [Digitial technology serving education in Africa]. Retrieved from http://unesdoc.unesco.org/images/0023/002312/231 278f.pdf

[2] Agence France-Presse (2017, April 19). Banque mondiale: prèsde 60 milliards US pour l'Afrique subsaharienne. [World Bank: Nearly \$6o billion for subSaharanAfrica]. La Presse. Retrieved from http://www.l apresse.ca/international/afrique/201703/19/01-5080163banque-mondiale-pres-de-60-milliards-us-pour-lafriquesubsaharienne.php

[3] Alexander, K. L., Entwisle, D. R., \& Horsey, C. S. (1997). From first grade forward: Early foundations of high school dropout.

Sociology of Education, 70(2), 87-107.

[4] Beegle, K., Christiaensen, L., Dabalen, A., \& Gaddis, I. (2017). La pauvreté dans une Afrique en essor: rapport sur la pauvreté en Afrique [Poverty in a booming continent: Report on poverty in Africa]. Retrieved from https://issuu.com/world.bank.publications/docs/978146480 9651

[5] Chen, J. J.-L. (2008). Grade-level differences: Relations of parental, teacher and peer support to academic engagement and achievement among Hong Kong students. School Psychology International, 29(2), 183-198.

[6] d'Aiglepierre, R. (2013). L'enseignement privé en Afrique subsaharienne : situations, enjeux et perspectives de partenariats public-privé [Private education in sub-Saharan Africa: Situations, challenges, and perspectives for publicprivate partnerships]. Retrieved from https://www.afd.f $\mathrm{r} / \mathrm{fr} /$ lenseignement-prive-en-afrique-subsaharienne-enjeuxsituations-et- perspectives-de-partenariats-public-prive

[7] Estell, D. B., \& Perdue, N. H. (2013). Social support and behavioral and affective school engagement: The effects of peers, parents, and teachers. Psychology in the Schools, 50(4), 325-339.
[8] Ending child marriage in Africa: A brief by Girls Not Brides (2015, March 20). Retrieved from http://girlsnotbrides.thei deabureau.netdna-cdn.com/wpcontent/uploads/2015/02/Child-marriage-in-Africa-Abrief-by-Girls- Not-Brides.pdf

[9] Hankivsky, O. (2008). Cost estimate of dropping out of high school in Canada. Journal of Applied Research on Learning, 1-85.

[10] Hillman A.L., \& Jenkner. E. (2004). L'éducation des enfants dans les pays pauvres [Education of children in poor countries]. FMI Publications.

[11] Inoue, K., di Gropello, E., Taylor, Y. S., \& Gresham, J. (2015). Les jeunes non scolarisés et déscolarisés d'Afrique subsaharienne: politiques pour le changement $\square$ Out-ofschool children in sub-Saharan Africa: Policies for change $\square$. Washington, DC: Banque internationale pour la reconstruction et le développement/La Banque mondiale.

[12] Koski, A., Clark, S., \& Nandi, A. (2017). Has child marriage declined in sub-Saharan Africa? An analysis of trends in 31 countries. Population and Development Review, 43(1), 7-29.

[13] Lanoue, É. (2006). Éducation, violences et conflits en Afrique subsaharienne: sources, données d'enquête (Côte d'Ivoire, Burkina Faso) et hypothèses [Education, violence and conflict in sub-Saharan Africa: data (Ivory Coast, Burkina Faso) and hypothesis]. In M. Pilon (Ed.), Défis du développement en Afrique subsaharienne: l'éducation en jeu [Challenges in sub- Saharan Africa: Education at stake] (pp. 222-242). Nogent-sur-Marne, France: CEPED.

[14] Lauwerier, T., \& Akkari, A. (2015). Les enseignants et la qualité de l'éducation de base en Afrique subsaharienne [Quality of basic education in sub-Saharan Africa]. Recherche et prospective en éducation, 11(1-10).

[15] Leridon, H. (2015). Afrique subsaharienne : une transition démographique explosive [sub-Saharan Africa: A demographic transition]. Futuribles, 407, 5-21.

[16] Martin, J.-Y. (2006). Quelles politiques éducatives pour quelle éducation dans les pays pauvres? [Educational policies in poor countries]. In M. Pilon (Ed.), Défis du développement en Afrique subsaharienne : l'éducation en jeu [Challenges in sub- Saharan Africa: Education at stake]. (pp. 147-161). Nogent-sur-Marne: CEPED.

[17] Moretti, E. (2007). Crime and costs of criminal justice. In C. R. Belfield and H. M. Levin (Eds.), The price we pay: Economic and social consequences of inadequate education (pp. 142-159). Washington, DC: Brookings Institution Press.

[18] Muennig, P. (2007). Consequences in health status and costs. In C. R. Belfield et H. M. Levin (Eds.), The price we pay: Economic and social consequences of inadequate education (pp. 125-141). Washington, DC: Brookings Institution Press.

[19] Raj, A., Saggurti, N., Balaiah, D., \& Silverman, J. G. (2009). Prevalence of child marriage and its effect on fertility and fertility- control outcomes of young women in 
India: A cross-sectional, observational study. The Lancet, 373(9678), 1883-1889.

[20] Rouse, C. E. (2007). Consequences for the labor market. In C. R. Belfield et H. M. Levin (Eds.). The price we pay: Economic and social consequences of inadequate education (pp. 99-124). Washington, DC: The Brookings Institution.

[21] Tabutin, D. (1991). La croissance démographique de l'Afrique: bilan et perspectives [Africa's population growth]. Revue Tiers- Monde, 32, 159-173.

[22] United Nations Educational, Scientific and Cultural Organization (UNESCO) (2002). Education for All Global Monitoring Report. Is the world on the track? Paris: UNESCO

[23] UNESCO. (2011). La crise cachée: les conflits armés et l'éducation [The hidden crisis: armed conflict and education]. Retrieved from http://unesdoc.unesco.org/ images /0019/001917/191794f.pdf

[24] UNESCO. (2012). Youth and skills: Putting education to work, EFA Global Monitoring Report, 2012. Retrieved from http://unesdoc.unesco.org/images/0021/002180/2180 03e.pdf

[25] UNESCO. (2017). 6 out of 10 children and adolescents are not a minimum in reading and math. Retrieved from http://uis.unesco.org/en/news/6-out-10-children-andadolescents-are-not-learning-minimum-readi ng -and-math

[26] UNICEF. (2013). Ending child marriage: Progress and prospects.Retrieved from https://www.un icef.org/me dia/files/Child_Marriage_Report_7_17_LR..pdf

[27] Yaro, Y., Adotevi-Dia, E., \& Dougnon, D. (2006) L'impact du sida sur l'offre et la demande scolaires en Afrique subsaharienne $\square$ The impact of AIDS in subSaharan Africa's education $\square$. In M. Pilon (Ed.), Défis du développement en Afrique subsaharienne: l'éducation en jeu [Challenges in sub-Saharan Africa: Education at stake]. (pp. 205-22). Nogent-sur-Marne: CEPED. 